\title{
Prevalence of External Parasites in Cattle Egret (Bubulcus Ibis) in Egypt
}

Salah Eldein, A. M. ${ }^{1 *}$; Abd El- Aal, A.A. ${ }^{2}$; Kamel, A. M. ${ }^{1}$ and GamalEldein, M.A ${ }^{1}$

${ }^{1}$ Department of Wildlife and Zoo Medicine, ${ }^{2}$ Department of Parasitology, Faculty of Veterinary Medicine, Suez Canal University

\begin{abstract}
:
The present study was aimed to determine the ectoparasites infested the cattle egrets (Bubulcus ibis) and its role in maintenance of such parasites in nature or transmission of these parasites to other species of wild and domestic birds especially after dramatic increase of cattle egret's population inside the urban areas. During this study, a total of 106 cattle egrets (Bubulcus ibis) were examined for the detection of external parasites of which 5 species ectoparasites; two lice, one tick larvae, one flea and one dipteran fly were detected. The detected ectoparasites were two lice sprcies Ciconiphilus decimfasciatus (67.92\%) and Menopon gallinae (45.28), one tick Argas persicus larvae (11.32), one fly Pseudolynchia sp. (9.43\%) and one flea Ctenocephalides canis $(1.88 \%)$. Five factors (habitat, area of collection, sex, age and season) affecting the prevalence of these parasites in cattle egrets were studied.
\end{abstract}

\section{Introduction:}

Cattle Egrets (Bubulcus ibis) are common birds with a worldwide distribution. They forage in fields with cattle and other livestock and nest in dense colonies, often in urban areas (Telfair, 1993). Cattle egret shares the human habitat (Subramanya, 1996) and forage on wastes and garbage (Javed, 1983) and also feed on invertebrate and fish (Seedikkoya, 2003). It plays role in management of insect pests in different agro-ecosystems (Yadav, 2000).

Wild birds harbor many species of ectoparasites such as lice, tick, mites, fleas and other blood sucking insects which affect directly on the general health condition of birds or indirectly transmit blood parasites to them or domestic birds (Abd $\boldsymbol{E l}$ Wahab, 1996). Cattle egret removes ticks and flies from cattle, but it can be implicated in the spread of tick borne animal diseases. (McCarthy, 2006).

The aim of this work is to study the prevalence of ectoparasites that can affect the cattle egret in two locality of Egypt, the possibility of transmission of such parasites to other species and also determine the relationship of five factors; habitat, area of collection (locality), season, age and sex of the cattle egret with 
the prevalence of ectoparasites in cattle egret.

\section{Material and Methods:}

During the period extended from September 2013 to Auguest 2014, one hundred and six cattle-egrets were hunted by net traps and divided into five groups according to: habitat (rubbish collecting areas in urban areas 24 and agriculture area 82), area of collection (Ismailia 44 and Sharkia 62), sex (male 68 and female 38), age (adult 46 and young 60) and season (Autumn 18, Winter 18, Spring 40 and Summer 30)

The investigated birds will be thoroughly and systematically examined using a piece of cotton soaked in ether from head, neck, wings and body by the naked eye and bright light with the aid of hand lens. The detected ectoparasites will be collected from different parts of the body by fine forceps.

The birds seem to be free from ectoparasites were dusted by pinch method (Hafez and Madboully, 1966), with insecticide powder and left for 15 minutes then the bird ruffled five times at interval of 5 minutes over a white sheet of paper. The ectoparasites were collected by fine hair brush. The collected ectoparasites from each bird will be placed in a separate vial containing suitable media for storage, alcohol glycerol (95\% ethanol and $5 \%$ glycerol) for identification (Hafez and Madboully, 1966).

Each vial will be labeled by fully data which include locality data of collection and serial number. The collected ectoparasites were put in lactophenol for clearing and mounted in polyvol (Baker and Warbton, 1959).

\section{Results and Discussion}

Prevalence of ectoparasites in the examined cattle egrets:

As shown in Table (1), the overall prevalence of external parasites in the current study was (69.81\%). A lower infestation rate was recorded by Amer and El Bashier (1994) (44.44 \%), Abd El-Wahab (1996) (57.14 \%), Dik and Halajian (2013) (15.2\%) in wild birds of Iran and Girisgin et al (2013) (58.8\%) in wild birds in northwestern Turkey.

In our opinion, the higher infestation rate of parasites in the current study may be related to the wide area of investigation (two governorates: Ismalia and Sharkia and two different habitats; Agriculture and Rubbish area).

Regarding to the detected ectoparsites, lice Ciconiphilus decimfasciatus (Fig. 1\&2) was revealed from $(67.92 \%)$ of the examined cattle egrets (Bubulcus ibis) in the present study. Both Hafez and Madbouly (1968) and Marietto-Gonçalves(2012) recorded Ciconiphilus decimfasciatus infested cattle egret. A lower prevalence was recorded by $\boldsymbol{A b \boldsymbol { b }} \boldsymbol{E \boldsymbol { l }}$ Wahab (1996) (54.76\%).

Chewing lice Ciconiphilus decimfasciatus is ectoparasites of birds that has adverse effect on the feather (Dik and Halajian, 2013). It 
causes pruritus, restlessness and the birds refuse feeding (Serra-Freire and Mello, 2006).

In the current study, the prevalence of lice Menopon gallinae (Fig. $4 \& 5)$ was $(45.28 \%)$ from the examined cattle egret. A lower prevalence was recorded by $A m e r$ and El Bashier (1994) (4.16\%) and Abd El- Wahab (1996) (38.9\%) while a higher prevalence was recorded by Khattak et al (2012) $(63.63 \%)$ in other birds.

Menopon gallinae is chewing or biting lice of poultry that effect on the vitality and productivity of birds. Such lice play an important role in transmission of fowl cholera, typhoid and toxoplasmosis (Saxena et al, 1985). Ruff (1999) stated that these lice retard the growth, lowered the vital activity and damage the health condition of the host.

The higher prevalence of lice in the current study may returned to the intensive population of cattle egrets, as the cattle egret was a gregarious bird make large colonies with other wading birds (del Hoyo et al, 1992). In our opinion, the mixed colonies of cattle egret may make it a source of ectoparasites infestation to other wild birds and also for the backyard domestic birds.

Tick Argas persicus larvae (Fig, 5), was revealed with a prevalence $(11.32 \%)$. This result was in agreement with the result recorded by Abd El-Wahab (1996) (11.90\%). Kaiser et al (1964); Kaiser and Hoogstraal (1969) and Guirgis
(1971) also recorded the infestation of cattle egret with Argas persicus larvae. A higher prevalence was recorded by Qamar et al (2009) $(56.71 \%)$ in the rural poultry at Lodhran, Pakistan.

Tick (Argas persicus) was a major external parasite responsible for low productivity in rural poultry (Qamar et al, 2009) and transmited Borrelia anserina which is the causative agent of fowl Spirochaetosis (Telmadarraiy et al, 2007).

From our opinion, the intensive population of cattle egret and the large mixed colonies over the trees may help in the spreading of Argas persicus infestation. Also the dispersal of cattle egret inside the urban areas making it a potential hazard to the backyard domestic birds.

In the current study, Pseudolynchia sp. fly was recovered from $(9.43 \%)$ of the examined cattle egrets (Bubulcus ibis). Gredilha et al (2008) recorded Pseudolynchia canariensis out of its natural host (Columba livia).

In our opinion, presence of Pseudolynchia sp. in cattle egret may give indication about the role of cattle egret in the preservation of such fly in the nature and may be aid in its propagation and transmission to pigeons.

Regarding to flea Ctenocephalides canis (Fig 6\&7), it was recorded in two birds only $(1.88 \%)$ from a total of 106 cattle egrets in the current study. Ctenocephalides canis (dog 
flea) was a species of flea that lives as an ectoparasite on a wide variety of mammals, particularly the domestic dog and cat. It fed on their blood; sometimes bite humans and was generally more prevalent worldwide (Linardi and Santos, 2012).

In our opinion, presence Ctenocephalides canis in cattle egret may be accidental as it recorded in two birds only but also may be an evidence for the role of cattle egret (Bubulcus ibis) in transmission of such flea to stray dogs and cats.

In the present study, five factors (habitat, area of collection, sex, age and season) affecting the prevalence of theses parasites in cattle egrets were studied.

Concerning the habitat as shown in Table (2), the general infestation of ectoparasites showed a significant difference in the agriculture habitat and the prevalence of the lice (Ciconiphilus decimfasciatus $75.6 \%$ and menopon gallinae 53.65\%) infestation showed a higher significance difference in the agriculture habitat $(\mathrm{P} \leq 0.01)$ and may be attributed to that the nests of cattle egrets were above the trees in large colonies around bodies of water (Telfair, 2006) in the agriculture areas, these intensive population of birds lead to a higher infestation with external parasites.

Regarding the area of collection (locality) as shown in Table (3), both the general infestation $(93.54 \%)$ and the infestation with lice Ciconiphilus decimfasciatus (93.54\%), Menopon gallinae (70.96\%) and tick Argas persicus larva (19.35) showed a higher significant difference $(\mathrm{P} \leq 0.01)$ in Sharkia due to the agriculture nature of the province with the increase of the colonies formation and the perfect habitat for breading which make the population of cattle egrets is intensive with a higher infestation with ectoparasites. While Pseudolynchia sp. (22.72\%) fly showed a higher significant difference $(P \leq 0.01)$ in Ismailia due to the increases in the rubbish and flies in the area of cattle egret aggregation.

Concerning to the sex as shown in Table (4), male cattle egrets showed a higher significant difference in general to the infestation $(\mathrm{P} \leq 0.01)$ of ectoparasites $(79.41 \%)$ and in the infestation of lice (Ciconiphilus decimfasciatus 79.41\%, Menopon gallinae $58.82 \%$ ) and that may return to the number of the collected samples, where the number of trapped males cattle egrets were nearly double the number of females samples.

Regarding to age as shown in Table (5), a higher significant difference between the young and adult $(\mathrm{P} \leq$ $0.01)$ was recorded where the general infestation $(96.66 \%)$ and the infestation with Ciconiphilus decimfasciatus (96.66\%), Menopon gallinae (73.33\%), tick Argas persicus larvae (20\%) appeared higher in the young age and that may explained as the cattle egret 
give 3-5 eggs and the incubation period lasts around 23 days, with both sexes sharing incubation duties and young birds stay in the nest for 45 till they become independent (Kushlan and Hancock, 2005) and the both sex rearing the young (Telfair, 2006) so high number of birds per nest (parents and 3 young at least) for long period (about 45 days) with the little movement of young in small nest may increase the infestation of young with external parasites. Also the immunity may play a role as reported by Qamar et al (2009) who recorded that the prevalence of Anti-Argas persicus antibodies was higher in adult poultry birds $(19.5 \%)$ than in young one $(9.08 \%)$ so the young has more tendency for infestation.

While Pseudolynchia sp. (21.73\%) showed a higher significant difference in the adult $(\mathrm{P} \leq 0.01)$ and that may explained on our opinion as most of the infested adult cattle egrets with Pseudolynchia sp. were trapped from the rubbish collecting area.

Concerning to seasons as shown in Table (6), the general prevalence of infestation with ectoparasites in cattle egret was (Autumn 55.55\%, Winter $33.33 \%$, Spring $95 \%$ and
Summer 66.66\%). A lower prevalence was recorded by $\boldsymbol{A b \boldsymbol { d }} \boldsymbol{E \boldsymbol { l }}$ Wahab (1996) (Autumn 23.25, Winter $40.98 \%$, Spring $50 \%$ and Summer 39.53\%).

In the current study, a higher significant difference $(\mathrm{P} \leq 0.01)$ in the general infestation of ectoparasites $(95 \%)$ and in the infestation of lice Ciconiphilus decimfasciatus (95\%) and Menopon gallinae $(65 \%)$ and a significant difference $(\mathrm{P} \leq 0.05)$ was showed in tick Argas persicus larvae (30\%) in the Spring and that may explained as the Spring and early Summer consider the breeding seasons of cattle egret (from March to October) (Skerrett et al, 2001) so increase the contact between birds during the breeding season and building the nest in large colonies, increase the possibility of the infestation with external parasites.

\section{Conclusion:}

Although the cattle egret has many benefits as a biological control for insects, agriculture and animals pests, the caution must be considered when dealing with it especially after the dramatic increase of its numbers in urban areas as it may transmit many ectoparasites to other wild and domestic birds. 
Table (1): Prevalence of different species of ectoparasites in cattle egrets.

\begin{tabular}{|c|c|c|}
\hline Ectoparasite species & $\begin{array}{c}\text { No. Of infested / No. of } \\
\text { examined }\end{array}$ & $\begin{array}{c}\text { Prevelance } \\
\%\end{array}$ \\
\hline Total ectoparasites & $74 / 106$ & 69.81 \\
\hline $\begin{array}{c}\text { Ciconiphilus } \\
\text { decimfasciatus }\end{array}$ & $72 / 106$ & 67.92 \\
\hline Menopon gallinae & $48 / 106$ & 45.28 \\
\hline Argas persicus larvae & $12 / 106$ & 11.32 \\
\hline Pseudolynchia sp. & $10 / 106$ & 9.43 \\
\hline Ctenocephalides canis & $2 / 106$ & 1.88 \\
\hline
\end{tabular}

Table (2): The prevalence of different ectoparasites in cattle egrets in relation to the habitat:

\begin{tabular}{|c|c|c|c|c|c|}
\hline Ectoparasites & Habitat & $\begin{array}{l}\text { No. of infested/ } \\
\text { No. of examined }\end{array}$ & Prevalence\% & $\mathbf{X}^{2}$ & $P$ value \\
\hline \multirow{2}{*}{ Ectoparasites } & Rubbish & $12 / 24$ & 50 & \multirow{2}{*}{4.626} & \multirow{2}{*}{$0.031^{*}$} \\
\hline & Agriculture & $62 / 82$ & 75.6 & & \\
\hline \multirow{2}{*}{$\begin{array}{c}\text { Ciconiphilus } \\
\text { decimfasciatus }\end{array}$} & Rubbish & $10 / 24$ & 41.66 & \multirow{2}{*}{8.32} & \multirow{2}{*}{$0.003^{* *}$} \\
\hline & Agriculture & $62 / 82$ & 75.6 & & \\
\hline \multirow{2}{*}{ menopon gallinae } & Rubbish & $4 / 24$ & 16.66 & \multirow{2}{*}{8.81} & \multirow{2}{*}{$0.003^{* *}$} \\
\hline & Agriculture & $44 / 82$ & 53.65 & & \\
\hline \multirow{2}{*}{$\begin{array}{l}\text { Argas persicus } \\
\text { larvae }\end{array}$} & Rubbish & $0 / 24$ & 0 & \multirow{2}{*}{2.63} & \multirow{2}{*}{0.104} \\
\hline & Agriculture & $12 / 82$ & 14.63 & & \\
\hline \multirow{2}{*}{ Pseudolynchia sp. } & Rubbish & $6 / 24$ & 25 & \multirow{2}{*}{6.6} & \multirow{2}{*}{0.102} \\
\hline & Agriculture & $4 / 82$ & 4.87 & & \\
\hline \multirow{2}{*}{$\begin{array}{c}\text { Ctenocephalides } \\
\text { canis }\end{array}$} & Rubbish & $0 / 24$ & 0 & \multirow{2}{*}{0.006} & \multirow{2}{*}{0.93} \\
\hline & Agriculture & $2 / 82$ & 2.43 & & \\
\hline
\end{tabular}

*(Significant difference $\mathrm{P} \leq 0.05) * *$ ( highly significant $\mathrm{P} \leq 0.01)$

Table (3): The prevalence of different ectoparasites in cattle egrets in relation to the area of collection.

\begin{tabular}{|c|c|c|c|c|c|}
\hline Ectoparasites & $\begin{array}{l}\text { Area of } \\
\text { collection }\end{array}$ & $\begin{array}{c}\text { No. of } \\
\text { infested/ No. } \\
\text { of examined }\end{array}$ & Prevalence\% & $\mathbf{X}^{2}$ & $P$ value \\
\hline \multirow{2}{*}{ EctoParasites } & Ismailia & $16 / 44$ & 36.36 & 37.26 & \multirow{2}{*}{$0.0001^{*}$} \\
\hline & Sharkia & $58 / 62$ & 93.54 & & \\
\hline \multirow{2}{*}{$\begin{array}{c}\text { Ciconiphilus } \\
\text { decimfasciatus }\end{array}$} & Ismailia & $14 / 44$ & 31.81 & \multirow{2}{*}{42.22} & \multirow{2}{*}{$0.0001^{*}$} \\
\hline & Sharkia & $58 / 62$ & 93.54 & & \\
\hline \multirow{2}{*}{ menopon gallinae } & Ismailia & $4 / 44$ & 9.09 & \multirow{2}{*}{37.31} & \multirow{2}{*}{$0.0001^{*}$} \\
\hline & Sharkia & $44 / 62$ & 70.96 & & \\
\hline
\end{tabular}




\begin{tabular}{|c|c|c|c|c|c|}
\hline \multirow{2}{*}{$\begin{array}{c}\text { Argas persicus } \\
\text { larvae }\end{array}$} & Ismailia & $0 / 44$ & 0 & \multirow{2}{*}{7.77} & \multirow{2}{*}{$0.005^{* *}$} \\
\hline & Sharkia & $12 / 62$ & 19.35 & & \\
\hline \multirow{2}{*}{ Pseudolynchia sp. } & Ismailia & $10 / 44$ & 22.72 & \multirow{2}{*}{13.01} & \multirow{2}{*}{$0.0003^{*}$} \\
\hline & Sharkia & $0 / 62$ & 0 & & \\
\hline \multirow{2}{*}{$\begin{array}{c}\text { Ctenocephalides } \\
\text { canis }\end{array}$} & Ismailia & $2 / 44$ & 4.54 & \multirow{2}{*}{0.94} & \multirow{2}{*}{0.33} \\
\hline & Sharkia & $0 / 62$ & 0 & & \\
\hline
\end{tabular}

\section{*(Significant difference $P \leq 0.05) * *$ ( highly significant $P \leq 0.01)$}

Table (4): The prevalence of different ectoparasites in cattle egrets in relation to the sex of cattle egrets:

\begin{tabular}{|c|c|c|c|c|c|}
\hline Ectoparasites & Sex & $\begin{array}{l}\text { No. of infested/ } \\
\text { No. of examined }\end{array}$ & $\begin{array}{c}\text { Prevalence } \\
\%\end{array}$ & $X^{2}$ & $P$ value \\
\hline \multirow{2}{*}{ EctoParasites } & Male & $54 / 68$ & 79.41 & 7.07 & \multirow{2}{*}{$0.007^{* *}$} \\
\hline & Female & $20 / 38$ & 52.63 & & \\
\hline \multirow{2}{*}{$\begin{array}{c}\text { Ciconiphilus } \\
\text { decimfasciatus }\end{array}$} & Male & $54 / 68$ & 79.41 & \multirow{2}{*}{10.06} & \multirow{2}{*}{$0.001^{* *}$} \\
\hline & Female & $18 / 38$ & 47.36 & & \\
\hline \multirow{2}{*}{$\begin{array}{l}\text { Menopon } \\
\text { gallinae }\end{array}$} & Male & $40 / 68$ & 58.82 & \multirow{2}{*}{12.5} & \multirow{2}{*}{$0.0004^{* *}$} \\
\hline & Female & $8 / 38$ & 21.05 & & \\
\hline \multirow{2}{*}{$\begin{array}{l}\text { Argas persicus } \\
\text { larvae }\end{array}$} & Male & $10 / 68$ & 14.7 & \multirow{2}{*}{1.32} & \multirow{2}{*}{0.24} \\
\hline & Female & $2 / 38$ & 5.26 & & \\
\hline \multirow{2}{*}{$\begin{array}{l}\text { Pseudolynchia } \\
\text { sp. }\end{array}$} & Male & $4 / 68$ & 5.88 & \multirow{2}{*}{1.76} & \multirow{2}{*}{0.18} \\
\hline & Female & $6 / 38$ & 15.78 & & \\
\hline \multirow{2}{*}{$\begin{array}{c}\text { Ctenocephalides } \\
\text { canis }\end{array}$} & Male & $0 / 68$ & 0 & \multirow{2}{*}{1.35} & \multirow{2}{*}{0.24} \\
\hline & Female & $2 / 38$ & 5.26 & & \\
\hline
\end{tabular}

*(Significant difference $\mathbf{P} \leq \mathbf{0 . 0 5}) * *($ highly significant $\mathbf{P} \leq \mathbf{0 . 0 1})$

Table (5): The prevalence of different ectoparasites in cattle egrets in relation to the age of cattle egrets.

\begin{tabular}{|c|c|c|c|c|c|}
\hline Ectoparasites & Age & $\begin{array}{l}\text { No. of infested/ } \\
\text { No. of } \\
\text { examined }\end{array}$ & $\begin{array}{c}\text { Prevalence } \\
\%\end{array}$ & $\mathbf{X}^{2}$ & $P$ value \\
\hline \multirow{2}{*}{ EctoParasites } & Adult & $16 / 46$ & 34.76 & \multirow{2}{*}{44.4} & \multirow{2}{*}{$0.0001^{* *}$} \\
\hline & Young & $58 / 60$ & 96.66 & & \\
\hline \multirow{2}{*}{$\begin{array}{c}\text { Ciconiphilus } \\
\text { decimfasciatus }\end{array}$} & Adult & $14 / 46$ & 30.43 & \multirow{2}{*}{49.2} & \multirow{2}{*}{$0.0001^{* *}$} \\
\hline & Young & $58 / 60$ & 96.66 & & \\
\hline \multirow{2}{*}{ Menopon gallinae } & Adult & $4 / 46$ & 8.69 & \multirow{2}{*}{41.32} & \multirow{2}{*}{$0.0001^{* *}$} \\
\hline & Young & $44 / 60$ & 73.33 & & \\
\hline \multirow{2}{*}{$\begin{array}{c}\text { Argas persicus } \\
\text { larvae }\end{array}$} & Adult & $0 / 46$ & 0 & \multirow{2}{*}{8.47} & \multirow{2}{*}{$0.0036^{* *}$} \\
\hline & Young & $12 / 60$ & 20 & & \\
\hline \multirow{2}{*}{ Pseudolynchia sp. } & Adult & $10 / 46$ & 21.73 & \multirow{2}{*}{11.97} & \multirow{2}{*}{$0.0005^{* *}$} \\
\hline & Young & $0 / 60$ & 0 & & \\
\hline \multirow{2}{*}{$\begin{array}{c}\text { Ctenocephalides } \\
\text { canis }\end{array}$} & Adult & $2 / 46$ & 4.34 & \multirow{2}{*}{0.82} & \multirow{2}{*}{0.36} \\
\hline & Young & $0 / 60$ & 0 & & \\
\hline
\end{tabular}


*(Significant difference $\mathbf{P} \leq \mathbf{0 . 0 5}) * *$ ( highly significant $\mathbf{P} \leq \mathbf{0 . 0 1}$ )

Table (6): The prevalence of different ectoparasites in cattle egrets relation to the season.

\begin{tabular}{|c|c|c|c|c|c|}
\hline Ectoparasites & Season & $\begin{array}{l}\text { No. of infested// } \\
\text { No. of examined }\end{array}$ & $\underset{\%}{\text { Prevalence }}$ & $\mathrm{X}^{2}$ & $\mathrm{P}$ value \\
\hline \multirow{4}{*}{ Ectoparasites } & Autumn & $10 / 18$ & 55.55 & 25.28 & \multirow{4}{*}{$0.0001^{* *}$} \\
\hline & Winter & $6 / 18$ & 33.33 & & \\
\hline & Spring & $38 / 40$ & 95 & & \\
\hline & Summer & $20 / 30$ & 66.66 & & \\
\hline \multirow{4}{*}{$\begin{array}{l}\text { Ciconiphilus } \\
\text { decimfasciatus }\end{array}$} & Autumn & $10 / 18$ & 55.55 & \multirow{4}{*}{32} & \multirow{4}{*}{$0.0001^{* *}$} \\
\hline & Winter & $4 / 18$ & 22.22 & & \\
\hline & Spring & $38 / 40$ & 95 & & \\
\hline & Summer & $20 / 30$ & 66.66 & & \\
\hline \multirow{4}{*}{$\begin{array}{l}\text { Menopon } \\
\text { gallinae }\end{array}$} & Autumn & $0 / 18$ & 0 & \multirow{4}{*}{27.65} & \multirow{4}{*}{$0.0001^{* *}$} \\
\hline & Winter & $4 / 18$ & 22.22 & & \\
\hline & Spring & $26 / 40$ & 65 & & \\
\hline & Summer & $18 / 30$ & 60 & & \\
\hline \multirow{4}{*}{$\begin{array}{c}\text { Argas persicus } \\
\text { larvae }\end{array}$} & Autumn & $0 / 18$ & 0 & \multirow{4}{*}{22.32} & \multirow{4}{*}{$0.0001^{* *}$} \\
\hline & Winter & $0 / 18$ & 0 & & \\
\hline & Spring & $12 / 40$ & 30 & & \\
\hline & Summer & $0 / 30$ & 0 & & \\
\hline \multirow{4}{*}{$\begin{array}{l}\text { Pseudolynchia } \\
\text { sp. }\end{array}$} & Autumn & $8 / 18$ & 44.44 & \multirow{4}{*}{33.17} & \multirow{4}{*}{$0.0001^{* *}$} \\
\hline & Winter & $2 / 18$ & 11.11 & & \\
\hline & Spring & $0 / 40$ & 0 & & \\
\hline & Summer & $0 / 30$ & 0 & & \\
\hline \multirow{4}{*}{$\begin{array}{l}\text { Ctenocephalides } \\
\text { canis }\end{array}$} & Autumn & $2 / 18$ & 11.11 & \multirow{4}{*}{9.96} & \multirow{4}{*}{$0.018^{*}$} \\
\hline & Winter & $0 / 18$ & 0 & & \\
\hline & Spring & $0 / 40$ & 0 & & \\
\hline & Summer & $0 / 30$ & 0 & & \\
\hline
\end{tabular}

*(Significant difference $\mathbf{P} \leq \mathbf{0 . 0 5}) * *$ ( highly significant $\mathbf{P} \leq \mathbf{0 . 0 1})$
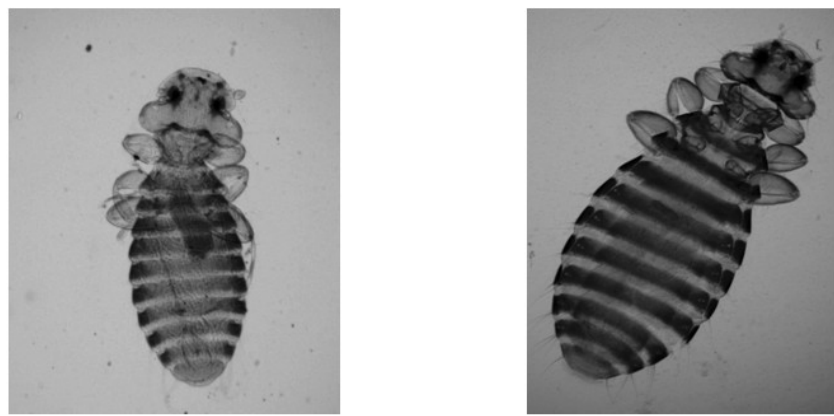

Fig. (1): Ciconiphilus decimfasciatus ( Male)

Fig. (2): Ciconiphilus decimfasciatus (Female) 
References:

Abdel-Wahab, A.M. (1996): Ectoparasites of some wild birds. MVSc. Thesis, Fac. Vet. Med. Zagazig Univ., Egypt.

Amer, O. H. and El Bashier, Z. M. (1994): Ectoparasites of wild birds in Egypt. Egyption J. Med. Microbiol., 3(10): 112-116.

Barker, E.W. and Warbton, G.W. (1959): An introduction to Acrarology $3^{\text {rd }}$ edition. The Macmillan Company, New York.

del Hoyo, J.; Elliot, A. and Sargatal, J. (1992): Handbook of the bird of the world. Vol 1. ostrich to duck. Lynx Edition, Barcelona, Spain.

Dik, B. and Halajian, A. (2013): Chewing lice (Phthiraptera) of several species of wild birds in Iran, with new records. J ArthropodBorne Dis., 7(1): 83-89.

Girisgin A. O.; Dik, B. and Girisgin, O. (2013): Chewing lice (Phthiraptera) species of wild birds in northwestern Turkey with a new host record. International Journal for Parasitology. Parasites and Wildlife, 2: 217-221.

Gredilha, R.; Balthazar, D. A.; Spadetti, A. L.; Fedull, F. P. and Mello, R. P. (2008): Pseudolynchia canariensis (Diptera

Hippoboscidae) on Buteogallus aequinoctialis (Ciconiiformes: Accipitridae) in the State of Rio de Janeiro, Brasil. Rev. Bras. Parasitol. Vet. (Online) 17(2) Jaboticabal.

Guirgis, S. S. (1971): Ecology and seasonal dynamics of Argus ( $p$ ) arboreus in Egypt. J. Med. Ent., 8 (4): 407-411.

Hafez. M. and Madbouly, M.H. (1966): Bird lice infesting domestic birds in Egypt (Mallophaga). Bull. Soc. Ent. Egypt, 51: 181- 213.

Hafez. M. and Madbouly, M.H. (1968): Mallophaga infesting resident birds in Egypt. I bid., 1(2):53-112

Javed, S. (1983): Scavenging by Cattle Egret. Newsletter for Bird Watchers, 33(2): 38.

Kaiser, M. N. and Hoogstraal $H$. and Khols, O. M. (1964): The subgenus Persicargus new subgenus (Ixodoidea : Argus). I. Argus (P)

Arboreus, new species, an Egyption like parasites of wild birds with reidentification of subgenus Argus. Ann. Ent. Soc.Amer. 57(1): 60-69.

Kaiser, M. N. and Hoogstraal $H$. (1969): The subgenus Persicargus (Ixodoidea : Argus). 7. A (P) Wallkarae, new species, a parasite of domestic fowl in South Africa. Ann. Of the Ent. Soc. of America, (62): 585-590.

Khattak, R. M.; Sharafat, A.; Jahangir, M.; Khan, M. N.; Rasul, A. and Iqbal, F. (2012): Prevalence of Ectoparasites in Wild and Domesticated Grey (Francolinus pondicerianus) and Black Partridges (Francolinus francolinus) from Khyber Pakhtoonkhwa Province of Pakistan. Pakistan J. Zool., 44(5): 1239-1244.

Kushlan, J A. and Hancock, J. (2005): Herons. Oxford University Press. 
Linardi, P. M. and Santos, J. L. C. (2012): Ctenocephalides felis felis vs. Ctenocephalides canis (Siphonaptera: Puulicidae): some issues in correctly identify these species. Rev. Bras. Parasitol. Vet., 21(4). Jaboticabal.

Marietto-Gonçalves,G.

A.;

Martins, T. F. and AndreattiFilho, R. L. (2012): Chewing lice (Insecta : Phthiraptera) parasitizing birds in Botucatu, SP, Brazil. R. bras. Ci. Vet., 19(3): 206-212.

McCarthy, E.M. (2006): Handbook of Avain Hybrids of the world. Oxford Univ. Press.

McKilligan, N.G. (1984): The food and feeding ecology of the cattle Egret Ardeola ibis when nesting in south-east Queensland. Australian Wildlife Research, 11(1): 133-144.

Qamar, M. F.; Sulehria, A. Q and Zahra, N. (2009): Prevalence of Argas persicus in rural poultry at Lodhran, Pakistan. Biologia (Pakistan), 55(1\&2): 87-92.

Ruff, M.D. (1999): Important parasites in poultry production systems. Vet. Parasistol., 843(4): 337-347.

Saxena, A.K.; Agarwal, G.P.; Chandra, S. and Singh, O.P. (1985): Pathogenic involvement of Mallophaga. Zur angewandte Entomologie, 99: 294-300.

Seedikkoya, K. (2003): Comparative ecology of certain paddy field birds with emphasis on the habitat quality. $\mathrm{PhD}$ Thesis, University of Calicut. Pp: 248.
Skerrett, A; Bullock, I. and Disley, T (2001): Birds of Seychelles. Helm Field Guides. Serra-freire, N.M. and Mello, R.P. (2006): Entomologia \& Acarologia.

Rio de Janeiro: L.F. Livros.

Subramanya, S. (1996):

Distribution, status and conservation of Indian

heronries. Journal of the Bombay Natural History Society, 93: 459486.

Telfair, R. C. (1993): The Cattle Egret: A Texas focus and world view. Texas Agricultural Experiment Station, College Station, Texas. Pp: 17-87.

Telfair, R. C. (2006): Cattle Egret (Bubulcus ibis), The Birds of North America Online (A. Poole, Ed.). Ithaca: Cornell Lab of Ornitholog.

Telmadarraiy, Z.; Nasirian, H.; Vatandoost, H.; Abuolhassani, M.; Tavakoli, M.; Zarei, Z.; Banafshi, O.; Rafinejad, J.; Salarielac, S. and Faghihi, F. (2007): Comparative susceptibility of Cypermethrin

Ornithodoros lahorensis Neuman and Argas persicus Oken (Acari: Argasidae) Field Populations. Pak. J. Bio. Sci., 23: 4315-4318.

Yadav, D.N. (2000): All India Network Project on Agricultural Ornithology, Annual Report. Gujarat Agricultural University, Anand. Pp: 1-14. 


\section{الملخص العربى}

\section{مدى تواجد الطفيليات الخارجية في طائر أبو قردان في مصر}

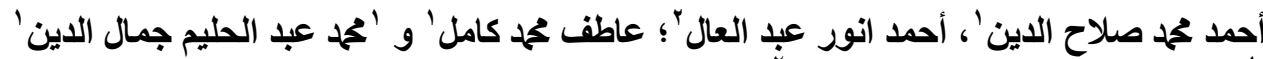

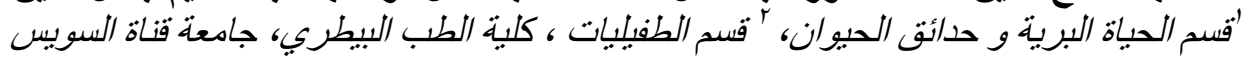

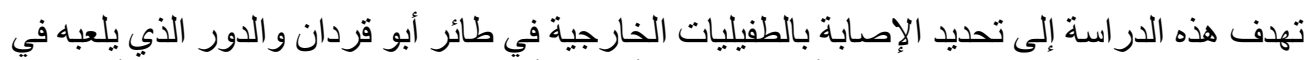

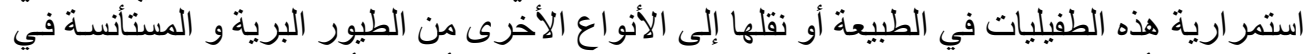

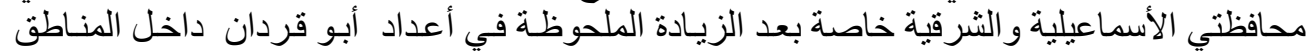

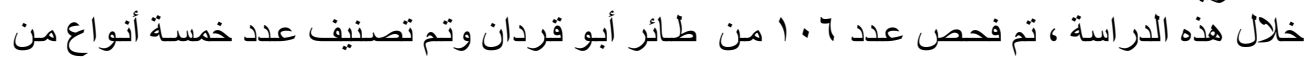

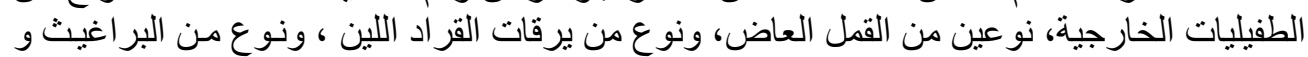
نوع من الذباب الطائر.

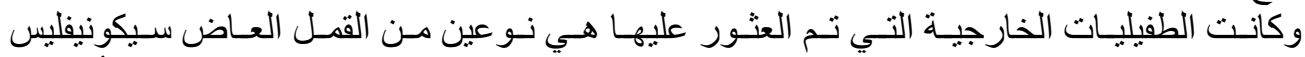

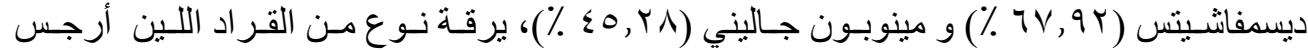

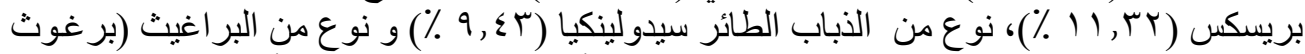

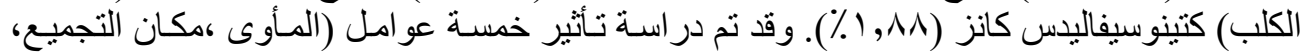
الجنس، العمر وفصول السنة) على مدى نو اجد هذه الطفيليات الخارجية على طلى طائر أبو قردان. 